\title{
Characterization of zinc vapor condensation in fly ash particles using synchrotron X-ray absorption spectroscopy*
}

\author{
Xu CAI, Qun-xing HUANG ${ }^{\dagger *}$, Moussa-mallaye ALHADJ-MALLAH, Yong CHI, Jian-hua YAN \\ (State Key Laboratory of Clean Energy Utilization, Institute for Thermal Power Engineering, \\ Zhejiang University, Hangzhou 310027, China) \\ †E-mail: hqx@zju.edu.cn
}

Received June 20, 2014; Revision accepted Nov. 6, 2014; Crosschecked Dec. 25, 2014

\begin{abstract}
Heavy metals released from municipal solid waste incinerators have become a major environmental concern. A comprehensive knowledge of metal vapor condensation in fly ash particles during incineration is essential for alleviating heavy metal toxicity, and for optimizing incineration process parameters and flue-gas cleaning systems. In this paper, the condensation of zinc vapor during flue-gas cooling in a $200 \mathrm{t} / \mathrm{d}$ fluidized bed incinerator and a $150 \mathrm{t} / \mathrm{d}$ moving grate incinerator was characterized and comparatively studied using high resolution synchrotron X-ray absorption spectroscopy (XAS). Principal component analysis, target transformation, and linear combination fitting were employed to identify zinc species directly from size fractionated fly ash particles. The chemical reaction behaviors of different zinc species were described by thermodynamic equilibrium simulations. Consistent with previous theoretical analysis and laboratory scale tests, the condensation behavior of zinc in an industrial incineration system is mainly affected by the sulfur/chlorine ratio and the inorganic particulates. It is found that zinc chloride is the major zinc species in a moving grate incinerator but willemite dominates in the fluidized bed incinerator. The high sulfur and silica/alumina particle concentration in the fluidized bed system changes the condensation propensity of vapors of $\mathrm{Zn}$ compounds. Adjusting the concentrations of $\mathrm{SO}_{2}$ in flue-gas can inhibit the formation of zinc chlorides. Silica, alumina, aluminosilicates, and calcium-based compounds are potential sorbents for transforming zinc to less harmful species. To prevent toxic zinc species contained in fine particles from escaping into the atmosphere, wet scrubbers are more suitable for cleaning flue-gases in moving grate incineration systems, while improving the efficiency of dust removal is more important for fluidized bed incineration systems.
\end{abstract}

Key words: Zinc speciation, Condensation, X-ray absorption spectroscopy (XAS), Solid waste doi:10.1631/jzus.A1400178 Document code: A CLC number: X506; X513

\section{Introduction}

It has been estimated that about 180 million metric tons (300 kg/yr per capita) of municipal solid waste (MSW) was generated in China in 2012. In-

\footnotetext{
$¥$ Corresponding author

* Project supported by the National Basic Research Program (973 Program) of China (No. 2011CB201500), the National Science \& Technology Pillar Program of China (No. 2012BAB09B03), and the National High-Tech R\&D Program (863 Program) of China (No. 2012AA063505)

(D) ORCID: Xu CAI, http://orcid.org/0000-0002-6620-057X; Qunxing HUANG, http://orcid.org/0000-0003-1557-3955

(c) Zhejiang University and Springer-Verlag Berlin Heidelberg 2015
}

cineration is a widely used technology for the rapid treatment of MSW, as it can significantly reduce the amount of waste by up to $90 \%$ in volume and $70 \%$ in weight, and recover energy (Abanades et al., 2005). Compared to other solid fuels, MSW has the distinct property of consisting of a large quantity of harmful heavy metals and high content of chlorine. The chlorine in the raw MSW will be initially oxidized into hydrogen chloride $(\mathrm{HCl})$, which in turn aides the vaporization of metals through the formation of gaseous metallic chlorides with relative high equilibrium saturation vapor pressure. The metal vapors will undergo nucleation/condensation upon flue-gas cooling and will form fine particles which are capable of 
penetrating conventional air pollution control (APC) systems and consequently impose direct health threats to local residents (Zhu et al., 2001; Xie et al., 2006).

The toxicity and mobilization of heavy metals in fly ash mainly depend on the chemical states of the metals, which may vary with the MSW composition, and the chemical reaction environment. Recent research shows that adopting mineral sorbents to capture the metallic vapors through either physical adsorption or chemical reaction can efficiently inhibit the formation of harmful metal compounds during flue-gas cooling (Gale and Wendt, 2002; Tran et al., 2004; Diaz-Somoano and Martínez-Tarazona, 2005), and many investigations have been carried out to characterize the condensation behavior of metal vapor in different environments for the selection of mineral sorbents and optimizing their effect (Belevi and Moench, 2000; Sørum et al., 2003). Song et al. (2013) studied theoretically the condensation behavior of $\mathrm{Pb}$ and $\mathrm{Zn}$ during oxy-fuel combustion as well as air-fired combustion. Jiao et al. (2013a; 2013b) reported that by changing the $\mathrm{SO}_{2}$ and steam concentrations in flue-gas in a tubular reactor, the deposition properties of metal vapors can be controlled. Previous research also indicates that the fate of the metallic species and their transformation pathways are important for developing an effective sorbentinjection methodology. However, due to restricted sampling conditions and lack of direct trace metal species identification methods, the actual metal vapor condensation behavior in a commercial scale furnace is still unclear.

$\mathrm{X}$-ray photoelectron spectroscopy and X-ray diffraction are widely used for species analysis (Narukawa et al., 2005; Kirpichtchikova et al., 2006), but their resolutions are insufficient for determining heavy metal speciation in fine fly ash particles because of the relatively low absolute concentrations present. Sequential chemical extraction is another widely used method for studying the behavior of heavy metals in different environments, but this may lead to alterations in the equilibrium between different chemical species, and it also suffers from low sensitivity, a lack of certified reference materials, and influences from the analytical conditions, which restrict its use for determining heavy metal species (Fernández et al., 2004; Narukawa et al., 2005; Yuan,
2009). High resolution X-ray absorption near-edge structure (XANES) spectroscopy and extended X-ray absorption fine structure (EXAFS) spectroscopy, using synchrotron X-ray beam sources, have been reported to be capable of acquiring metal species in solid samples directly, even if the element of interest is present at very low concentrations (Manceau et al., 2004; Struis et al., 2004; Strawn and Baker, 2009).

This study aims to extend previous laboratory studies to practical systems. The condensation of semi-volatile metal zinc (Hasselriis and Licata, 1996), during flue-gas cooling in different commercial MSW incineration systems was studied by X-ray absorption spectroscopy (XAS). $\mathrm{Zn}$ is a widely used material, in galvanization, alloys, and batteries (Wan et al., 2006). In China, $\mathrm{Zn}$ has the highest concentration of all heavy metals in raw MSW and incinerator residues. Oxidized $\mathrm{Zn}$ is a soluble and mobile trace metal under acidic conditions, making it one of the most phytotoxic microelements (Roberts et al., 2002), and zinc extraction toxicity is still included in the criteria for hazardous wastes identification in many countries (Hesterberg et al., 1997; Sinclair et al., 2010). In this study, $\mathrm{Zn}$ composition and speciation in sized fly ash particles collected from hot flue-gases after the heat recovery unit and before APC system in a $200 \mathrm{t} / \mathrm{d}$ circulating fluidized bed (CFB) and a $150 \mathrm{t} / \mathrm{d}$ moving grate incinerator are analyzed with XANES and EXAFS spectroscopy. A thermal equilibrium calculation is also employed to describe $\mathrm{Zn}$ speciation behavior during the flue-gas cooling process.

\section{Materials and methods}

\subsection{Samples}

Two different types of fine fly ash particles were studied. The first two samples, M1 and M2, were collected from the Hangzhou Lvneng MSW power plant, which has an inclined reverse moving grate incinerator. The other two samples, $\mathrm{C} 1$ and $\mathrm{C} 2$, were collected from the Hangzhou Jingjiang MSW power plant, where pre-shredded waste with $12.2 \%$ coal is burned in a CFB incinerator. The capacities of the moving grate incinerator and the CFB incinerator were 150 and $200 \mathrm{t} / \mathrm{d}$, respectively. These two plants are in the same area in Hangzhou City, and are fed 
with MSW which comes from the same waste transfer station. Table 1 lists the properties of MSW and coal. The data in Table 1 was the average MSW composition burned during ash sampling period. The data was obtained manually according to Chinese standard CJ/T 313-2009.

Table 1 Properties of MSW and coal used in two incineration plants

\begin{tabular}{lcc}
\hline \multirow{2}{*}{ Property } & \multicolumn{2}{c}{ Value } \\
\cline { 2 - 3 } & MSW & Coal \\
\hline Proximate analysis & & \\
Moisture (\%, in weight) & 51.98 & 4.32 \\
Ash (\%, in weight) & 24.31 & 24.55 \\
Volatile matter (\%, in weight) & 18.82 & 28.30 \\
Fixed carbon (\%, in weight) & 4.89 & 42.83 \\
Higher heating value (kJ/kg) & 4221 & 22922 \\
\hline Ultimate analysis (\%, in weight, as received) \\
Carbon & 14.24 \\
Hydrogen & 1.98 & 59.75 \\
Nitrogen & 0.31 & 4.08 \\
Oxygen & 7.13 & 0.83 \\
Sulfur & 0.05 & 0.43 \\
Chlorine & 0.39 & 0.07 \\
\hline
\end{tabular}

Samples were collected using a cascade impactor (Osán et al., 2010) (WY-II, Beijing Daziran Co., Ltd., China), which was inserted vertically into the flue after the heat recovery unit and before the flue-gas cleaning system, where the time average flue-gas temperature was around $420 \mathrm{~K}$. Fig. 1 indicates the sampling point of the incineration system. The WY-II cascade impactor has eight stages and can capture particles of between $0.33 \mu \mathrm{m}$ and $9.8 \mu \mathrm{m}$. The aerodynamic cut-off diameters of the eight stages are $9.8,6.7,4.3,2.6,1.81,1.06$, and $0.67 \mu \mathrm{m}$, respectively. The final stage was fitted with a $0.33 \mu \mathrm{m}$ pore size quartz-fiber filter-paper. The cut-off diameter of the different stages strongly depends on the flue-gas temperature and pressure. For our experiments, each sampling lasted around $2 \mathrm{~h}$ to capture enough particles for analysis. Due to the variation in the burned MSW, the flue-gas temperature and pressure were fluctuating all the time during sampling (although the fluctuation is under control, it still strongly affects the sampling. The temperature ranged between $136{ }^{\circ} \mathrm{C}$ and $168{ }^{\circ} \mathrm{C}$. The relative pressure ranged between
$-2.49 \mathrm{kPa}$ and $-2.04 \mathrm{kPa}$ ). The cut-off size of each stage is also changing and the size distribution of particles captured in connecting stages may be overlapped, especially for stages after 5. To avoid any misunderstanding and to make the results representative, we merged the particles into two big groups. Fine particles $(<2.5 \mu \mathrm{m}$; samples M1 and C1) which were deposited in stages $5-8$, and coarse particles (2.5-9.8 $\mu \mathrm{m}$; samples M2 and $\mathrm{C} 2$ ) which were deposited on stages 2-4, were collected for $\mathrm{Zn}$ analysis. Collected samples were stored in vacuum centrifuge tubes to keep them free of water vapor or oxygen before they were analyzed by XAS.

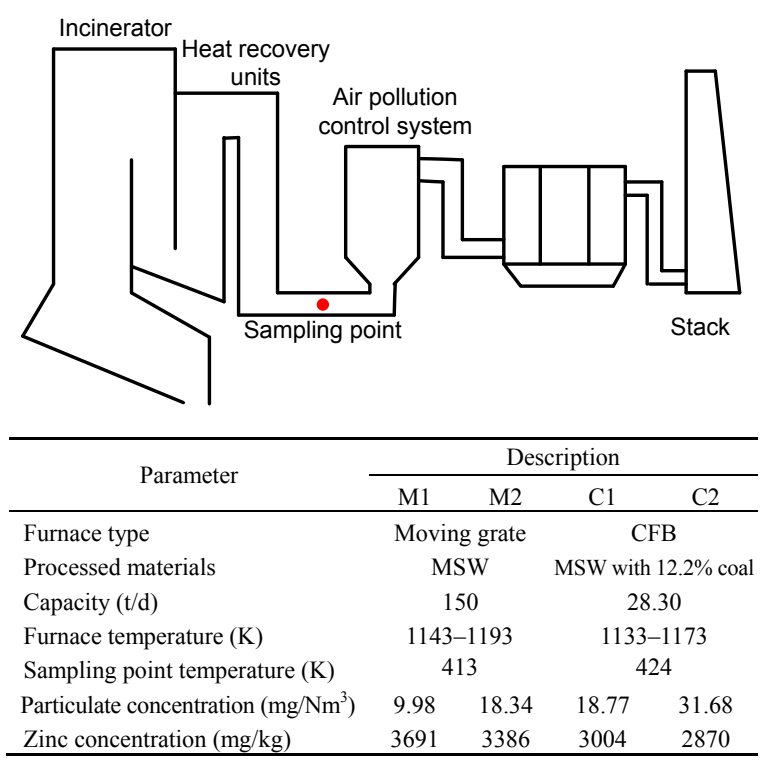

Fig. 1 Position of the sampling point in the MSW incineration furnace and sample parameters

Analytical grade $\mathrm{ZnO}, \mathrm{ZnCl}_{2}, \mathrm{ZnS}, \mathrm{ZnSO}_{4} \cdot 7 \mathrm{H}_{2} \mathrm{O}$, hydrozincite $\left(\mathrm{Zn}_{5}\left(\mathrm{CO}_{3}\right)_{2}(\mathrm{OH})_{6}\right)$, willemite $\left(\mathrm{Zn}_{2} \mathrm{SiO}_{4}\right)$, and gahnite $\left(\mathrm{ZnAl}_{2} \mathrm{O}_{4}\right)$ were used as reference materials according to previous studies (Shoji et al., 2002; Manceau et al., 2004; Struis et al., 2004; Osán et al., 2010). The reference materials were provided by Sinopharm Chemical Reagent Co., Ltd. (China) and Aladdin Industrial Inc. (USA). The purity of reference materials is $>99 \%$ (for hydrozincite and willemite $>98 \%$ ).

For calibration purposes, the total $\mathrm{Zn}$ concentration was determined before the $\mathrm{Zn}$ species were measured using the synchrotron XAS. Each sample was dried at $378 \mathrm{~K}$ for about $2 \mathrm{~h}$ and digested in a 
mixture of $\mathrm{HNO}_{3}, \mathrm{HF}$, and $\mathrm{HClO}_{4}$ in a microwave oven. The $\mathrm{Zn}$ ion concentration in the filtered solution was analyzed by inductively coupled plasma mass spectrometry (Xeries II, Thermo Fisher Scientific Inc., USA).

\subsection{XAS measurements}

Zn K-edge XAS measurements were carried out at the BL14W1 beam line station at the Shanghai Synchrotron Radiation Facility Center (SSRF). The electron storage ring was operated at $3.5 \mathrm{GeV}$ to yield an electron beam with an average current of $300 \mathrm{~mA}$. Each sample was packed in a polycarbonate container and sealed with polyimide tape. The K-edge XAS spectra of the $\mathrm{Zn}$ species were measured with a double crystal $\mathrm{Si}$ (111) monochromator, which was used to select the incident beam energy and decrease the harmonics. The monochromator position was calibrated by assigning the first inflection point of the $\mathrm{K}$-edge of metallic $\mathrm{Zn}$ foil to $9659 \mathrm{eV}$. The reference material spectra were recorded in transmission mode using ionization chambers, and sample spectra were recorded in fluorescent mode using a Lytle detector (Huggins et al., 2000). A standard $\mathrm{Zn}$ foil was mounted between two ionization chambers, downstream of the sample, to allow the energy to be calibrated using the first inflection point of the $\mathrm{Zn}$ foil absorption edge. The XANES and EXAFS scanning step sizes were $0.5 \mathrm{eV} /$ point and $1.0 \mathrm{eV} /$ point, respectively (Hecht et al., 1996). According to the fundamental of SSRF, the uncertainty for XAS measurement is lower than $0.005 \%(5-20 \mathrm{keV})$. All spectra were measured at room temperature $(298 \mathrm{~K})$, and duplicate scanning was carried out for all samples; the maximum fluctuation of the spectrum was less than $2 \%$.

\subsection{X-ray absorption spectrum processing}

The XAS spectral analyses were performed using the Athena, Artemis (Ravel and Newville, 2005), and SIXpack (Webb, 2005) modules in the IFEFFIT XAS analysis software package (Newville, 2001). The threshold energy $\left(E_{0}\right)$ was taken at the zerocrossing point of the second derivative of the experimental spectrum, and raw data were linearly calibrated against the difference between the measured $E_{0}$ and the theoretical absorption edge energy for the $\mathrm{Zn} \mathrm{K}$-edge at $9659 \mathrm{eV}$. Linear pre-edge fitting and second-order polynomial post-edge fitting were performed to subtract the background signal and to normalize the spectra.

Principal component analysis (PCA) and target transformation (Ressler et al., 2000) were used to identify $\mathrm{Zn}$ species that could have been present in the samples. The SPOIL parameter (Webb, 2005), which is a non-negative dimensionless number, indicates the fitting error increment in the target transformation resulting from replacing an abstract principal component with a candidate spectrum. According to previous work on metal species (Manceau et al., 2002; Webb, 2005), a SPOIL value of $<3.0$ is good, a value between 3.0 and 4.5 is acceptable, and a value $>4.5$ is unacceptable. Least-squares linear combination fitting was performed to determine the fractional contribution of each reference compound identified in the samples, by comparing the fitted spectrum with the experimental measurements. The residuals $(\mathrm{Re})$, defined as the normalized root square difference between the experimental data and the fit, were minimized during the fitting process. The combination of low signal-to-noise ratio, background noise, and the inherent heterogeneity of fly ash matrix is likely to result in an estimated error that is greater than $\pm 3 \%$ of the total metal content quoted. We considered that the individual contribution of a reference compound determined to be $<5 \%$ of the total $\mathrm{Zn}$ content was unacceptable.

EXAFS data extraction was performed using standard methods (Roberts et al., 2002), extracting the $k^{3}$-weighted chi spectra $\left(\chi(k) \cdot k^{3}\right)$ from the raw data and then performing a Fourier transformation over the range of $15-120 \mathrm{~nm}^{-1}$. The amplitude and phase shift functions were generated by FEFF 7.0 based on the $\mathrm{Zn}$ reference structure. Multi-shell fitting was performed in $R$ space over the range $0.1 \mathrm{~nm}<R<0.35 \mathrm{~nm}$. The interatomic distance $(R)$ resolutions were estimated to be $\pm 0.002 \mathrm{~nm}$ and $\pm 0.005 \mathrm{~nm}$ for the first and second shells, respectively. The amplitude reduction factor $\left(S_{0}^{2}\right)$ was 0.9 , as recommended by Struis et al. (2004).

\section{Results and discussion}

\section{1 $\mathrm{Zn}$ distribution in particulates}

As a semi-volatile metal, the total $\mathrm{Zn}$ concentration in fly ash particles depends to a significant 
extent on the combustion temperature and $\mathrm{O}_{2}$ concentration inside the furnace (van der Sloot et al., 2001). The parameters and particle size distribution of samples are displayed in Fig. 1 and Fig. 2, respectively. The moving grate incinerator and the CFB incinerator had different combustion characters, more large particles were carried in the flue-gas from the CFB incinerator. The total particle concentration (Fig. 1) in the CFB incinerator is twice as much as that in moving grate system. However, the PM2.5/PM10 (PMx: particles with aerodynamic diameters less than $x$ micrometers) mass concentration ratio was higher in the moving grate incinerator. The combustion temperature inside the furnace $(>1123 \mathrm{~K})$ was much higher than the boiling point of $\mathrm{Zn}(692.5 \mathrm{~K})$ or $\mathrm{ZnCl}_{2}$ $(1005 \mathrm{~K})$, so metallic zinc had a tendency to homogeneous nucleation and be enriched in smaller particles (Chang et al., 2000) causing the total concentrations in our samples $(2870-3691 \mathrm{mg} / \mathrm{kg})$ to be much higher than the average $\mathrm{Zn}$ concentration in fly ashes captured by the APC system $(2000-2500 \mathrm{mg} / \mathrm{kg}$ ). Meanwhile, the total $\mathrm{Zn}$ concentrations were higher in $\mathrm{M} 1$ and M2 than in $\mathrm{C} 1$ and $\mathrm{C} 2$. We also found that the $\mathrm{Zn}$ concentrations were $20 \%$ higher in the fine particles compared with the coarse particles.

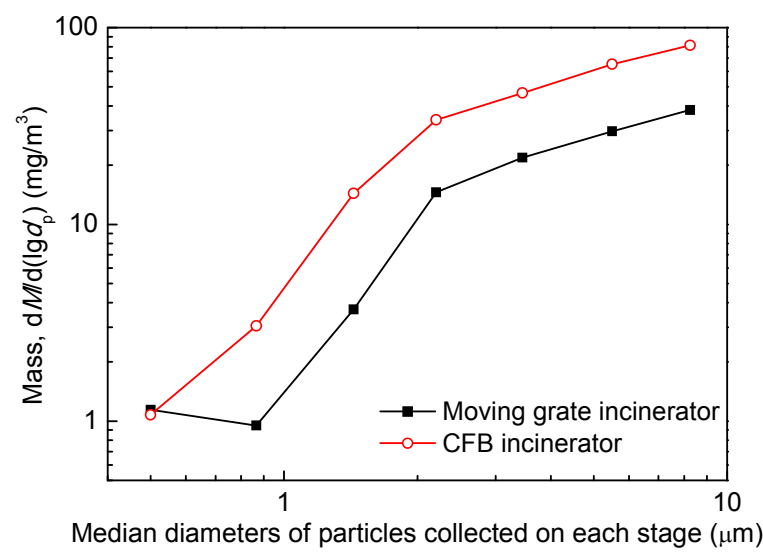

Fig. 2 Particle size distribution of particulate samples from the incinerators, collected using a cascade impactor

Verhulst et al. (1995) and Wang et al. (1999) reported that high chloride content in waste will favor the formation of volatile heavy metal compounds in fly ash particles. Fuel in the CFB incinerator has a lower chloride content because coal is added, which may explain why samples M1 and M2 contain higher Zn concentrations.

\subsection{PCA analyses and linear combination fitting of XAS spectra}

Due to the excellent quality of the synchrotron $\mathrm{X}$-ray system and an advanced data processing algorithm, the detection limit and spectrum uncertainty are less than $0.003 \%$ and $2 \%$, respectively, for the measured Zinc species. The normalized Zn K-edge XANES spectra and $k^{3}$-weighted EXAFS spectra for the four fly ash particle samples and seven $\mathrm{Zn}$ standards are shown in Fig. 3. PCA and target transformations were performed on both the XANES and EXAFS spectra. The SPOIL values found from both the XANES and EXAFS spectra of the reference compounds are listed in Table 2, and it can be seen that willemite $\left(\mathrm{Zn}_{2} \mathrm{SiO}_{4}\right)$, zinc chloride $\left(\mathrm{ZnCl}_{2}\right)$, hydrozincite $\left(\mathrm{Zn}_{5}\left(\mathrm{CO}_{3}\right)_{2}(\mathrm{OH})_{6}\right)$, zincite $(\mathrm{ZnO})$, and
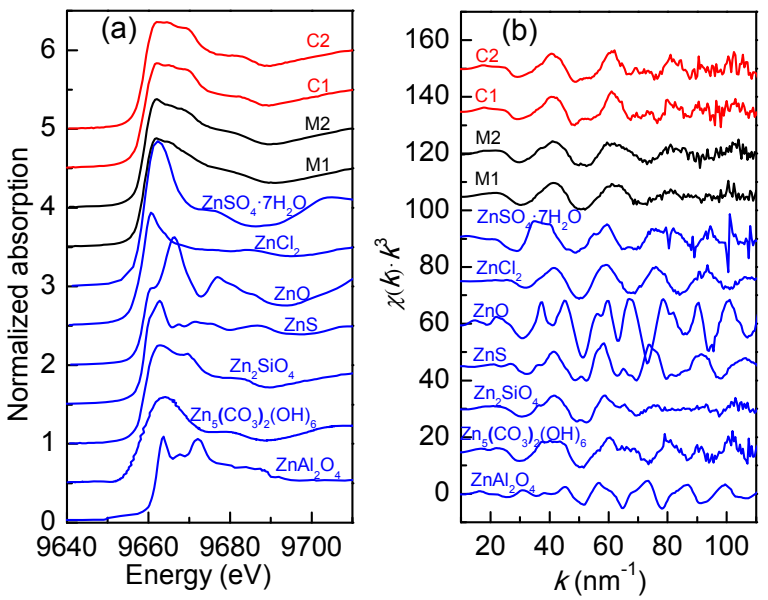

Fig. 3 Normalized Zn K-edge XANES spectra (a) and $\boldsymbol{k}^{3}$-weighted EXAFS spectra (b) of the fly ash samples and zinc standards

Table 2 Target transformation results for the $\mathrm{Zn}$ K-edge XANES and $\boldsymbol{k}^{3}$-weighted EXAFS spectra of the phases that could be present

\begin{tabular}{lcc}
\hline \multicolumn{1}{c}{$\begin{array}{l}\text { Reference } \\
\text { compound }\end{array}$} & $\begin{array}{c}\text { XANES } \\
\text { SPOIL }^{\mathrm{a}}\end{array}$ & $\begin{array}{c}\text { EXAFS } \\
\text { SPOIL }^{\mathrm{b}}\end{array}$ \\
\hline $\mathrm{Zn}_{2} \mathrm{SiO}_{4}$ & 2.14 & 3.52 \\
$\mathrm{Zn}_{5}\left(\mathrm{CO}_{3}\right)_{2}(\mathrm{OH})_{6}$ & 3.34 & 4.33 \\
$\mathrm{ZnO}$ & 3.66 & 3.33 \\
$\mathrm{ZnCl}_{2}$ & 4.23 & 1.65 \\
$\mathrm{ZnSO}_{4} \cdot 7 \mathrm{H}_{2} \mathrm{O}$ & 7.61 & 2.89 \\
$\mathrm{ZnAl}_{2} \mathrm{O}_{4}$ & 2.75 & 3.63 \\
$\mathrm{ZnS}$ & 6.68 & 11.26 \\
\hline
\end{tabular}

${ }^{\mathrm{a}}$ XANES spectra energy range is $9640-9710 \mathrm{eV} ;{ }^{\mathrm{b}} k^{3}$-weighted EXAFS spectra $k$ range is $25-110 \mathrm{~nm}^{-1}$ 
gahnite $\left(\mathrm{ZnAl}_{2} \mathrm{O}_{4}\right)$ were potentially found in all the fly ash samples. Zinc sulfate $\left(\mathrm{ZnSO}_{4} \cdot 7 \mathrm{H}_{2} \mathrm{O}\right)$ has a relative high XANES SPOIL value but a low EXAFS SPOIL value, so this could also have been present in the samples. $\mathrm{ZnS}$ is volatile and unstable under oxidizing conditions (Verhulst et al., 1995), and, because of its high SPOIL value and thermodynamic behavior, no $\mathrm{ZnS}$ seems to have been present in the samples analyzed.

The normalized experimental EXAFS data were calculated for each sample, by least-squares linear combination fitting, to obtain the mass ratio of each reference compound in the sample. Fig. 4 shows the experimental and linear combination fitting results for the EXAFS spectra. Quantitative $\mathrm{Zn}$ speciation results for each of the samples are shown in Table 3 and Fig. 5. The relative uncertainty for the fitting results in Table 3 is about $\pm 2 \%$. The linear combination fitting results showed that the $\mathrm{Zn}$ speciation in the particulate samples was very different in different furnace types. $\mathrm{Zn}$ was present as a mixture of zinc chloride $(41 \%-48 \%)$, willemite $(19 \%-24 \%)$, gahnite $(14 \%-16 \%)$, zincite $(11 \%-13 \%)$, and zinc sulfate (about 7\%) in the moving grate samples. Willemite was the dominant $\mathrm{Zn}$ species in the CFB samples (37\%-44\%), with zinc chloride $(20 \%-25 \%)$, zincite $(8 \%)$, gahnite $(8 \%-10 \%)$, and zinc sulfate $(12 \%)$ also being present. Hydrozincite was not found in the moving grate samples, but was found at less than $10 \%$

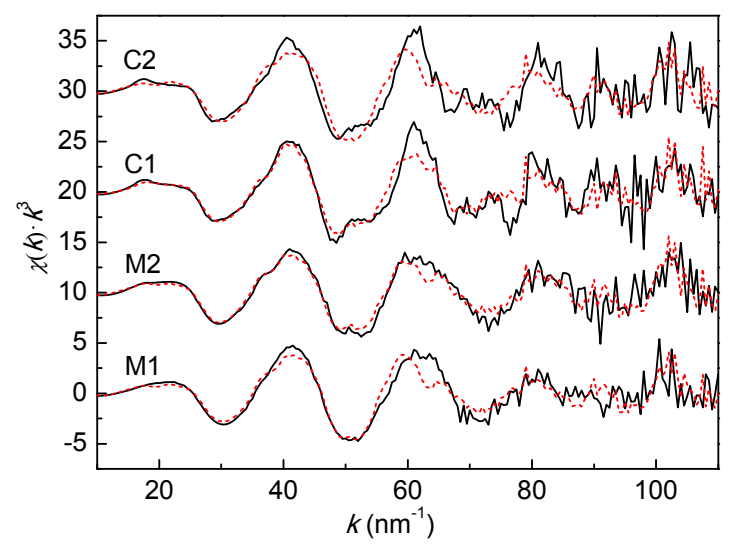

Fig. 4 Experimental and linear combination fitting results for $Z n$ from the normalized $\boldsymbol{k}^{3}$-weighted EXAFS spectra of the fly ash samples

The solid lines are the raw data, and the dotted lines are the fitted results from linear combinations of the chi data of the total $\mathrm{Zn}$ concentration in the CFB samples. Zinc chloride and zincite were enriched in the fine particle samples (M1 and C1), whereas willemite and zinc sulfate were present at higher concentrations in the larger particle samples (M2 and $\mathrm{C} 2$ ), which matches the results for big particles (captured by bag filter and electrostatic precipitator) found by Takaoka et al. (2005). Zinc chloride would have been concentrated in the fly ash particles through homogeneous nucleation and heterogeneous deposition when the flue-gas temperature decreased. However, willemite in the fine particles would have been entrained by the flue-gas leaving the furnace; the different migration pathways lead to different results.

Table 3 Contributions (of total $\mathrm{Zn}$ ) of the reference compounds to the $\mathrm{Zn}$ in the fly ash samples, derived from principal component analyses, target transformation, linear combination fitting, and the best-fit residue values (Re)

\begin{tabular}{lcccc}
\hline \multirow{2}{*}{\multicolumn{1}{c}{ Item }} & \multicolumn{4}{c}{ Contribution (\%) } \\
\cline { 2 - 5 } & $\mathrm{M} 1$ & $\mathrm{M} 2$ & $\mathrm{C} 1$ & $\mathrm{C} 2$ \\
\hline $\mathrm{Zn}_{5}\left(\mathrm{CO}_{3}\right)_{2}(\mathrm{OH})_{6}$ & 0 & 0 & 8 & 6 \\
$\mathrm{Zn}_{2} \mathrm{SiO}_{4}$ & 19 & 24 & 37 & 44 \\
$\mathrm{ZnSO}_{4}$ & 6 & 8 & 11 & 14 \\
$\mathrm{ZnAl}_{2} \mathrm{O}_{4}$ & 14 & 16 & 10 & 8 \\
$\mathrm{ZnO}$ & 13 & 11 & 9 & 8 \\
$\mathrm{ZnCl}$ & 48 & 41 & 25 & 20 \\
\hline $\operatorname{Re}(\%)$ & 1.7 & 1.2 & 2.4 & 1.6 \\
\hline
\end{tabular}

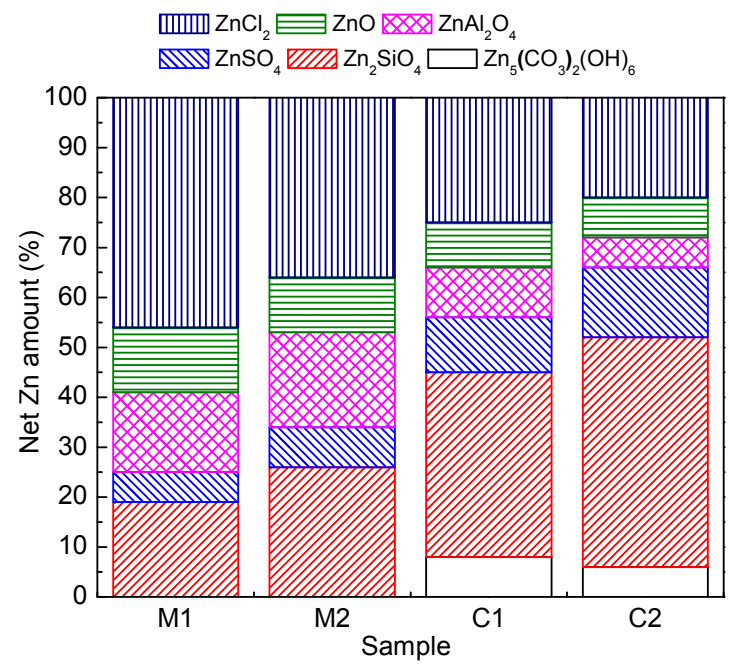

Fig. 5 Quantitative $\mathrm{Zn}$ speciation results for fly ash samples collected from two furnaces 


\subsection{Zinc coordination chemistry by EXAFS}

EXAFS analysis was used to confirm the states of the $\mathrm{Zn}$ species. The fitting results for the reference compounds and samples, obtained by the nonlinear, least-squares fitting of individual coordination shells, are presented in Table 4. Zn was found to be tetrahedrally coordinated to both $\mathrm{O}$ and $\mathrm{Cl}$ in sample $\mathrm{M} 1$. The second shell contribution could be fitted with $\mathrm{Zn}$ at a distance of $0.322 \mathrm{~nm}$. The coordination numbers and distances in the $\mathrm{O}$ shell and the $\mathrm{Zn}$ shell agreed with those of $\mathrm{ZnO}$. The coordination numbers and distances in the $\mathrm{Cl}$ shell were consistent with $\mathrm{ZnCl}_{2}$. The linear combination fitting results for the fine particles from the CFB incinerator gave an estimate of $46 \% \mathrm{ZnCl}_{2}$ and $13 \% \mathrm{ZnO}$ being present. The sample M2 data gave a $\mathrm{Zn}-\mathrm{O}$ distance of $0.196 \mathrm{~nm}$, and the second shell could be fitted with $\mathrm{Zn}$ at a distance of $0.324 \mathrm{~nm}$. The coordination numbers and distances in the $\mathrm{O}$ shell were similar to those of $\mathrm{ZnO}$ and $\mathrm{Zn}_{2} \mathrm{SiO}_{4}$. The distance in the $\mathrm{Zn}$ shell was close to the distances in these two compounds, with an intermediate $\mathrm{Zn}$ shell coordination number. The EXAFS data therefore showed that sample M2 probably contained a mixture of $\mathrm{ZnO}$ and $\mathrm{Zn}_{2} \mathrm{SiO}_{4}$, which agreed with the linear combination fitting results. The coordination numbers and distances in the $\mathrm{O}$ shell and $\mathrm{Zn}$ shell for samples $\mathrm{C} 1$ and $\mathrm{C} 2$ were almost the same as those of $\mathrm{Zn}_{2} \mathrm{SiO}_{4}$, which confirms the presence of willemite in the particulates from the CFB incinerator.

\subsection{Equilibrium calculation and changes in $\mathrm{Zn}$ species}

The equilibrium composition of the $\mathrm{Zn}$ species between 673-1573 K were simulated with FactSage software (Thermfact/CRCT, Montreal, Canada \& GTT-Technologies, Herzogenrath, Germany). The conditions defined for the FactSage simulation were based on the average operation parameters and measured MSW composition. The equilibrium amounts of zinc species are shown in Fig. 6. These results can qualitatively explain the $\mathrm{Zn}$ speciation in fly ash particles and describe the mobilization of different $\mathrm{Zn}$ species during the flue-gas cooling process. $\mathrm{ZnO}$ found in the fine fly ash particles is a high-temperature oxidation product. The reaction of $\mathrm{ZnCl}_{2}$ with $\mathrm{CaO}$ or $\mathrm{Ca}(\mathrm{OH})_{2}$ (derived from the hydration of $\mathrm{CaO}$ ) are possible contributors to $\mathrm{ZnO}$ formation. After leaving the furnace, some of the $\mathrm{ZnO}$ will react with $\mathrm{CO}_{2}$ and $\mathrm{H}_{2} \mathrm{O}$ and be transformed into $\mathrm{Zn}_{5}\left(\mathrm{CO}_{3}\right)_{2}(\mathrm{OH})_{6}$ at a relatively low temperature (Hales and Frost, 2008).

$$
2 \mathrm{ZnCl}_{2}+\mathrm{CaO}+\mathrm{H}_{2} \mathrm{O} \rightarrow 2 \mathrm{ZnO}+\mathrm{CaCl}_{2}+2 \mathrm{HCl}
$$

$\mathrm{ZnO} / \mathrm{ZnCl}_{2}$ reacted with $\mathrm{Al}_{2} \mathrm{O}_{3} / \mathrm{SiO}_{2}$ to form wellemite/gahnite during the cooling process. There

Table 4 Fitted structural parameters for the reference compounds and the fly ash samples: coordination number $(N)$, interatomic distance $(R)$, and Debye-Waller factor $\left(\sigma^{2}\right)$

\begin{tabular}{|c|c|c|c|c|c|c|c|c|}
\hline \multirow{2}{*}{ Sample } & \multicolumn{4}{|c|}{ First shell } & \multicolumn{4}{|c|}{ Second shell } \\
\hline & Atoms & $N$ & $R(\mathrm{~nm})$ & $\sigma^{2}\left(\times 10^{-5} \mathrm{~nm}^{2}\right)$ & Atoms & $N$ & $R(\mathrm{~nm})$ & $\sigma^{2}\left(\times 10^{-5} \mathrm{~nm}^{2}\right)$ \\
\hline $\mathrm{ZnO}$ & $\mathrm{Zn}-\mathrm{O}$ & 3.9 & 0.197 & 5.2 & $\mathrm{Zn}-\mathrm{Zn}$ & 6.1 & 0.323 & 3.6 \\
\hline $\mathrm{Zn}_{5}(\mathrm{OH})_{6}\left(\mathrm{CO}_{2}\right)_{3}$ & $\mathrm{Zn}-\mathrm{O}$ & 4.1 & 0.202 & 4.7 & $\mathrm{Zn}-\mathrm{Zn}$ & 2.3 & 0.322 & 6.3 \\
\hline $\mathrm{Zn}_{2} \mathrm{SiO}_{4}$ & $\mathrm{Zn}-\mathrm{O}$ & 4.2 & 0.196 & 3.1 & $\mathrm{Zn}-\mathrm{Zn}$ & 3.1 & 0.325 & 7.9 \\
\hline $\mathrm{ZnSO}_{4} \cdot 7 \mathrm{H}_{2} \mathrm{O}$ & $\mathrm{Zn}-\mathrm{O}$ & 5.9 & 0.201 & 6.8 & $\mathrm{Zn}-\mathrm{Zn}$ & 2.2 & 0.338 & 9.1 \\
\hline $\mathrm{ZnS}$ & $\mathrm{Zn}-\mathrm{S}$ & 3.8 & 0.234 & 3.7 & $\mathrm{Zn}-\mathrm{Zn}$ & 12.0 & 0.384 & 7.6 \\
\hline $\mathrm{ZnCl}_{2}$ & $\mathrm{Zn}-\mathrm{Cl}$ & 4.0 & 0.231 & 4.1 & & & & \\
\hline $\mathrm{ZnAl}_{2} \mathrm{O}_{4}$ & $\mathrm{Zn}-\mathrm{O}$ & 4.0 & 0.197 & 3.3 & $\mathrm{Zn}-\mathrm{Al}$ & 12.1 & 0.335 & 4.2 \\
\hline \multirow[t]{2}{*}{ M1 } & $\mathrm{Zn}-\mathrm{O}$ & 4.2 & 0.197 & 9.2 & $\mathrm{Zn}-\mathrm{Zn}$ & 3.9 & 0.322 & 7.8 \\
\hline & $\mathrm{Zn}-\mathrm{Cl}$ & 3.8 & 0.229 & 7.4 & & & & \\
\hline M2 & $\mathrm{Zn}-\mathrm{O}$ & 4.0 & 0.196 & 6.5 & $\mathrm{Zn}-\mathrm{Zn}$ & 5.5 & 0.324 & 4.1 \\
\hline $\mathrm{C} 1$ & $\mathrm{Zn}-\mathrm{O}$ & 3.9 & 0.195 & 6.6 & $\mathrm{Zn}-\mathrm{Zn}$ & 3.3 & 0.325 & 10.1 \\
\hline $\mathrm{C} 2$ & $\mathrm{Zn}-\mathrm{O}$ & 4.1 & 0.195 & 8.2 & $\mathrm{Zn}-\mathrm{Zn}$ & 2.8 & 0.323 & 6.7 \\
\hline
\end{tabular}

Note: fit quality limits for the parameters: $|\Delta R|<0.002 \mathrm{~nm}$ for the first shell; $|\Delta R|<0.005 \mathrm{~nm}$ for the second shell 
was a large amount of silica/alumina inside the CFB incinerator as bed material, which explained the high willemite and gahnite content found in samples $\mathrm{C} 1$ and $\mathrm{C} 2$ (Yu et al., 2012). The reaction between $\mathrm{SiO}_{2}$ and $\mathrm{ZnO} / \mathrm{ZnCl}_{2}$ at temperatures above $1073 \mathrm{~K}$ creates a lot of $\mathrm{Zn}_{2} \mathrm{SiO}_{4}$, and strong flue-gas turbulence and a uniform temperature distribution will promote this reaction.

$$
\begin{gathered}
\mathrm{ZnCl}_{2}+\mathrm{Al}_{2} \mathrm{O}_{3}+\mathrm{H}_{2} \mathrm{O} \rightarrow \mathrm{ZnAl}_{2} \mathrm{O}_{4}+2 \mathrm{HCl} \\
2 \mathrm{ZnCl}_{2}+\mathrm{SiO}_{2}+2 \mathrm{H}_{2} \mathrm{O} \rightarrow \mathrm{Zn}_{2} \mathrm{SiO}_{4}+4 \mathrm{HCl} \\
2 \mathrm{ZnO}+\mathrm{SiO}_{2} \rightarrow \mathrm{Zn}_{2} \mathrm{SiO}_{4} .
\end{gathered}
$$

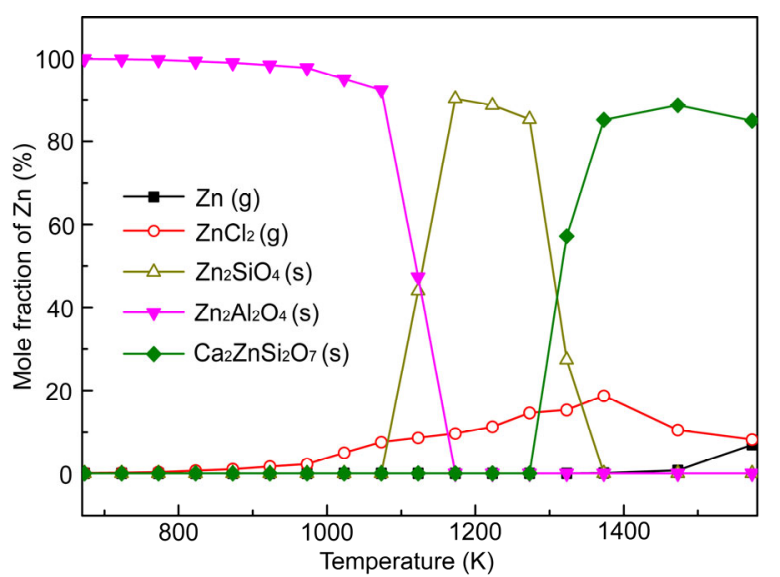

(a)

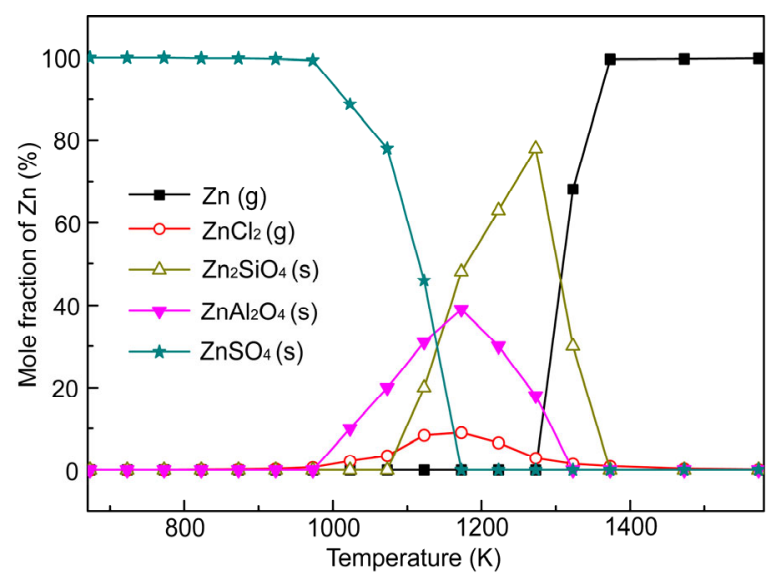

(b)

Fig. 6 Equilibrium distribution of $\mathrm{Zn}$ during incineration of only MSW, low content of sulfur (a), and MSW with coal, high content of sulfur (b)

At low temperatures, the presence of sulfur leads to zinc sulfate being formed, displacing the chloride and sometimes the oxide.

$$
\mathrm{ZnCl}_{2}+\mathrm{SO}_{2}+1 / 2 \mathrm{O}_{2}+\mathrm{H}_{2} \mathrm{O} \rightarrow \mathrm{ZnSO}_{4}+2 \mathrm{HCl}
$$

$\mathrm{ZnS}$ would also form in some areas with low local oxygen concentrations, but it is unstable under the oxidizing conditions that prevail in a furnace, and it will be oxidized to $\mathrm{ZnSO}_{4}$ at a low temperature or to $\mathrm{ZnO}$ at a high temperature (Verhulst et al., 1995). The relatively high $\mathrm{ZnSO}_{4}$ content in the CFB samples was caused by the use of coal, which has a relatively high sulfur concentration, in the CFB incinerator.

The chloride component concentrations were higher in the moving grate incinerator samples than in the CFB incinerator samples. Test results confirm that with a higher ratio of sulfur/chloride in the furnace, less chloride will be formed. The higher ratio of sulfur/chloride in CFB flue-gas and the existence of silica/alumina particles shift the transformation of zinc from chlorides toward other compounds. Corrosion and attrition will be less serious in a CFB incinerator than in a moving grate incinerator. Sulfur recirculation and sulfur-based sorbents might be a practicable method to reduce chlorides in fly ash.

Metal fume fever is associated with the inhalation of $\mathrm{ZnO}$ fumes. $\mathrm{ZnCl}_{2}$ inhalation causes alveolar edema by damaging alveolar surface proteins, causing elevated lavage fluid production. To avoid these problems it is necessary to prevent fine particles containing $\mathrm{Zn}$ species from escaping into the atmosphere. $\mathrm{ZnCl}_{2}$ and $\mathrm{ZnSO}_{4}$ are highly soluble in water, $\mathrm{Zn}_{5}\left(\mathrm{CO}_{3}\right)_{2}(\mathrm{OH})_{6}, \mathrm{ZnAl}_{2} \mathrm{O}_{4}$, and $\mathrm{ZnO}$ can react with acids (the first flue-gas scrubbing step) and alkalis. From the point of view of $\mathrm{Zn}$ removal and metal recycling, a wet scrubber is the best flue-gas cleaning process for a moving grate incineration system. When a high proportion of $\mathrm{ZnCl}_{2}, \mathrm{ZnO}, \mathrm{ZnAl}_{2} \mathrm{O}_{4}$, $\mathrm{Zn}_{5}\left(\mathrm{CO}_{3}\right)_{2}(\mathrm{OH})_{6}$, and $\mathrm{ZnSO}_{4}$ is present, as in the moving grate samples, a considerable amount (about $80 \%$ ) of $\mathrm{Zn}$ will be removed at the same time with acid gas. $Z n$ will be enriched in the scrubbing liquid, and can be recycled. The main $\mathrm{Zn}$ species in the CFB incinerator samples was willemite, which is relatively stable during acid flue-gas removing, and improving the dust removal efficiency in CFB incinerators will be of great benefit. 


\section{Conclusions}

To characterize zinc vapor condensation behavior in a commercial scale MSW incineration system, four fly ash samples collected before the APC unit of a $200 \mathrm{t} / \mathrm{d}$ CFB and a $150 \mathrm{t} / \mathrm{d}$ moving grate MSW incinerator, respectively, were experimentally studied. The trace $\mathrm{Zn}$ species were determined directly using XANES and EXAFS spectroscopy. The results show that zinc chloride is the major species in fly ash collected from the moving grate system, and willemite dominates in the CFB system. Compared to laboratory scale tests, more metal species were observed due to the complex waste composition and chemical reaction environment. From the point of view of metal leaching, moving grate ashes are much more toxic. The ratio of sulfur/chloride can alter the condensation propensity of $\mathrm{Zn}$, and adjusting the concentrations of $\mathrm{SO}_{2}$ in flue-gas can prevent the formation of zinc chloride. Silica, alumina, aluminosilicates, and calcium-based compounds are potential sorbents for transforming zinc to an environmentally benign form. To prevent toxic zinc species contained fine particles from escaping into the atmosphere, wet scrubbers are more suitable for cleaning flue-gases in moving grate incineration systems, while increasing dust removal efficiency is more important for fluidized bed incineration systems.

\section{References}

Abanades, S., Flamant, G., Gauthier, D., et al., 2005. Development of an inverse method to identify the kinetics of heavy metal release during waste incineration in fluidized bed. Journal of Hazardous Materials, 124(1-3):19-26. [doi:10.1016/j.jhazmat.2005.05.004]

Belevi, H., Moench, H., 2000. Factors determining the element behavior in municipal solid waste incinerators. 1. field studies. Environmental Science \& Technology, 34(12): 2501-2506. [doi:10.1021/es991078m]

Chang, M.B., Huang, C.K., Wu, H.T., et al., 2000. Characteristics of heavy metals on particles with different sizes from municipal solid waste incineration. Journal of Hazardous Materials, 79(3):229-239. [doi:10.1016/ S0304-3894(00)00277-6]

Diaz-Somoano, M., Martínez-Tarazona, M.R., 2005. Hightemperature removal of cadmium from a gasification flue-gas using solid sorbents. Fuel, 84(6):717-721. [doi:10.1016/j.fuel.2004.11.006]

Fernández, E., Jimenez, R., Lallena, A.M., et al., 2004. Eval- uation of the BCR sequential extraction procedure applied for two unpolluted Spanish soils. Environmental Pollution, 131(3):355-364. [doi:10.1016/j.envpol.2004. 03.013]

Gale, T.K., Wendt, J.O.L., 2002. High-temperature interactions between multiple-metals and kaolinite. Combustion and Flame, 131(3):299-307. [doi:10.1016/S0010-2180(02) 00404-2]

Hales, M., Frost, R., 2008. Thermal analysis of smithsonite and hydrozincite. Journal of Thermal Analysis and Calorimetry, 91(3):855-860. [doi:10.1007/s10973-007-8571-0]

Hasselriis, F., Licata, A., 1996. Analysis of heavy metal emission data from municipal waste combustion. Journal of Hazardous Materials, 47(1-3):77-102. [doi:10.1016/ 0304-3894(95)00107-7]

Hecht, D., Frahm, R., Strehblow, H.H., 1996. Quick-scanning EXAFS in the reflection mode as a probe for structural information of electrode surfaces with time resolution: an in situ study of anodic silver oxide formation. The Journal of Physical Chemistry, 100(26):10831-10833. [doi:10. 1021/jp9610574]

Hesterberg, D., Sayers, D.E., Zhou, W.Q., et al., 1997. X-ray absorption spectroscopy of lead and zinc speciation in a contaminated groundwater aquifer. Environmental Science \& Technology, 31(10):2840-2846. [doi:10.1021/ es970077w]

Huggins, F.E., Shah, N., Huffman, G.P., et al., 2000. XAFS spectroscopic characterization of elements in combustion ash and fine particulate matter. Fuel Processing Technology, 65-66:203-218. [doi:10.1016/S0378-3820(99)00089-2]

Jiao, F., Zhang, L., Yamada, N., et al., 2013a. Effect of $\mathrm{HCl}$, $\mathrm{SO}_{2}$ and $\mathrm{H}_{2} \mathrm{O}$ on the condensation of heavy metal vapors in flue-gas cooling section. Fuel Processing Technology, 105:181-187. [doi:10.1016/j.fuproc.2011.06.024]

Jiao, F., Zhang, L., Song, W., et al., 2013b. Effect of inorganic particulates on the condensation behavior of lead and zinc vapors upon flue-gas cooling. Proceedings of the Combustion Institute, 34(2):2821-2829. [doi:10.1016/j.proci. 2012.07.062]

Kirpichtchikova, T.A., Manceau, A., Spadini, L., et al., 2006. Speciation and solubility of heavy metals in contaminated soil using X-ray microfluorescence, EXAFS spectroscopy, chemical extraction, and thermodynamic modelling. Geochimica et Cosmochimica Acta, 70(9):2163-2190. [doi:10.1016/j.gca.2006.02.006]

Manceau, A., Marcus, M.A., Tamura, N., 2002. Quantitative speciation of heavy metals in soils and sediments by synchrotron X-ray techniques. Reviews in Mineralogy and Geochemistry, 49(1):341-428. [doi:10.2138/gsrmg. 49.1.341]

Manceau, A., Marcus, M.A., Tamura, N., et al., 2004. Natural speciation of $\mathrm{Zn}$ at the micrometer scale in a clayey soil using X-ray fluorescence, absorption, and diffraction. Geochimica et Cosmochimica Acta, 68(11):2467-2483. 
[doi:10.1016/j.gca.2003.11.021]

Narukawa, T., Takatsu, A., Chiba, K., et al., 2005. Investigation on chemical species of arsenic, selenium and antimony in fly ash from coal fuel thermal power stations. Journal of Environmental Monitoring, 7(12):1342-1348. [doi:10.1039/b509817c]

Newville, M., 2001. IFEFFIT: interactive XAFS analysis and FEFF fitting. Journal of Synchrotron Radiation, 8(2): 322-324. [doi:10.1107/S0909049500016964]

Osán, J., Meirer, F., Groma, V., et al., 2010. Speciation of copper and zinc in size-fractionated atmospheric particulate matter using total reflection mode X-ray absorption near-edge structure spectrometry. Spectrochimica Acta Part B: Atomic Spectroscopy, 65(12):1008-1013. [doi:10.1016/j.sab.2010.11.002]

Ravel, B., Newville, M., 2005. ATHENA, ARTEMIS, HEPHAESTUS: data analysis for X-ray absorption spectroscopy using IFEFFIT. Journal of Synchrotron Radiation, 12(4):537-541. [doi:10.1107/S0909049505012719]

Ressler, T., Wong, J., Roos, J., et al., 2000. Quantitative speciation of Mn-bearing particulates emitted from autos burning (methylcyclopentadienyl) manganese tricarbonyladded gasolines using XANES spectroscopy. Environmental Science \& Technology, 34(6):950-958. [doi:10. 1021/es990787x]

Roberts, D.R., Scheinost, A.C., Sparks, D.L., 2002. Zinc speciation in a smelter-contaminated soil profile using bulk and microspectroscopic techniques. Environmental Science \& Technology, 36(8):1742-1750. [doi:10.1021/ es015516c]

Shoji, T., Huggins, F.E., Huffman, G.P., et al., 2002. XAFS spectroscopy analysis of selected elements in fine particulate matter derived from coal combustion. Energy \& Fuels, 16(2):325-329. [doi:10.1021/ef010200b]

Sinclair, A.H., Edgerton, E.S., Wyzga, R., et al., 2010. A two-time-period comparison of the effects of ambient air pollution on outpatient visits for acute respiratory illnesses. Journal of the Air \& Waste Management Association, 60(2):163-175. [doi:10.3155/1047-3289.60.2.163]

Song, W., Jiao, F., Yamada, N., et al., 2013. Condensation behavior of heavy metals during oxy-fuel combustion: deposition, species distribution, and their particle characteristics. Energy \& Fuels, 27(10):5640-5652. [doi:10. 1021/ef400484p]

Sørum, L., Frandsen, F.J., Hustad, J.E., 2003. On the fate of heavy metals in municipal solid waste combustion. Part I: devolatilisation of heavy metals on the grate. Fuel, 82(18):2273-2283. [doi:10.1016/S0016-2361(03)00178-9]

Strawn, D.G., Baker, L.L., 2009. Molecular characterization of copper in soils using X-ray absorption spectroscopy. Environmental Pollution, 157(10):2813-2821. [doi:10.1016/ j.envpol.2009.04.018]

Struis, R.P.W.J., Ludwig, C., Lutz, H., et al., 2004. Speciation of zinc in municipal solid waste incineration fly ash after heat treatment: an X-ray absorption spectroscopy study. Environmental Science \& Technology, 38(13):37603767. [doi:10.1021/es0346126]

Takaoka, M., Yamamoto, T., Tanaka, T., et al., 2005. Direct speciation of lead, zinc and antimony in fly ash from waste treatment facilities by XAFS spectroscopy. Physica Scripta, T115:943-945. [doi:10.1238/Physica.Topical. 115a00943]

Tran, Q.K., Steenari, B.M., Iisa, K., et al., 2004. Capture of potassium and cadmium by kaolin in oxidizing and reducing atmospheres. Energy \& Fuels, 18(6):1870-1876. [doi:10.1021/ef049881b]

van der Sloot, H.A., Kosson, D.S., Hjelmar, O., 2001. Characteristics, treatment and utilization of residues from municipal waste incineration. Waste Management, 21(8): 753-765. [doi:10.1016/S0956-053X(01)00009-5]

Verhulst, D., Buekens, A., Spencer, P.J., et al., 1995. Thermodynamic behavior of metal chlorides and sulfates under the conditions of incineration furnaces. Environmental Science \& Technology, 30(1):50-56. [doi:10.1021/ es940780+]

Wan, X., Wang, W., Ye, T., et al., 2006. A study on the chemical and mineralogical characterization of MSWI fly ash using a sequential extraction procedure. Journal of Hazardous Materials, 134(1-3):197-201. [doi:10.1016/j. jhazmat.2005.10.048]

Wang, K.S., Chiang, K.Y., Lin, S.M., et al., 1999. Effects of chlorides on emissions of toxic compounds in waste incineration: study on partitioning characteristics of heavy metal. Chemosphere, 38(8):1833-1849. [doi:10.1016/ S0045-6535(98)00398-1]

Webb, S.M., 2005. SIXpack: a graphical user interface for XAS analysis using IFEFFIT. Physica Scripta, T115:1011-1014. [doi:10.1238/Physica.Topical.115a010 11]

Xie, R., Seip, H.M., Wibetoe, G., et al., 2006. Heavy coal combustion as the dominant source of particulate pollution in Taiyuan, China, corroborated by high concentrations of arsenic and selenium in PM10. Science of the Total Environment, 370(2-3):409-415. [doi:10.1016/j. scitotenv.2006.07.004]

Yu, J., Sun, L., Xiang, J., et al., 2012. Vaporization of heavy metals during thermal treatment of model solid waste in a fluidized bed incinerator. Chemosphere, 86(11):11221126. [doi:10.1016/j.chemosphere.2011.12.010]

Yuan, C.G., 2009. Leaching characteristics of metals in fly ash from coal-fired power plant by sequential extraction procedure. Microchimica Acta, 165(1-2):91-96. [doi:10. 1007/s00604-008-0103-5]

Zhu, Y.J., Olson, N., Beebe, T.P., 2001. Surface chemical characterization of $2.5-\mu \mathrm{m}$ particulates (PM2.5) from air pollution in Salt Lake City using TOF-SIMS, XPS, and FTIR. Environmental Science \& Technology, 35(15): 3113-3121. [doi:10.1021/es0019530] 


\section{中文概要}

题 目: 基于同步辐射技术研究金属锌蒸汽在飞灰小颗粒 表面的凝结特性

目 的: 寻找金属污染物在热转化过程中的生成和迁移规 律, 为可燃固体废弃物高效清洁能源化利用提供 科学指导。

方 法: 飞灰采自两台不同类型在运行固废焚烧炉; 采样 位置位于烟气净化系统之前以规避干扰; 利用同
步辐射技术中的 X 射线近边吸收结构和吸收精细 结构谱图结合热力学模拟对金属锌的形态进行分 析和研究。

结 论：1. 金属锌在炉排炉飞灰小颗粒上主要以氯化物形 式存在, 而在流化床飞灰小颗粒上是以铝硅酸盐 为主; 2 . 燃烧过程中的高硫氮比能够有效减少锌 有毒形态的生成; 3. 硅、铝和钙基材料是锌蒸汽 有效的吸附剂。

关键词: 锌形态; 冷凝特性; 同步辐射; 固体废弃物 